\title{
Effectivity of Probiotic, Micromineral Enriched Yeast and Their Combination with Azadirachta indica Leaves Containing Tannin on Fermentability and Digestibility of Pennisetum hybrid
}

\author{
Sofyan A, Sakti AA, Karimy MF, Julendra H, Istiqomah L, Herdian H, Damayanti E, Suryani AE \\ Division of Animal Feed and Nutrition, Research Unit for Processes Development and Chemical Engineering (BPPTK), \\ Indonesian Institute of Sciences (LIPI), Jl. Jogja-Wonosari Km. 31.5, Gading, Playen, Gunungkidul, DI Yogyakarta 55861 \\ Telephone/Faximile: 0274-392570/391168 \\ E-mail:sofyan_lipi@yahoo.co.id/ahmad.sofyan@lipi.go.id
}

(received 16-02 2015; revised 13-03-2015; accepted 17-03-2015)

\begin{abstract}
ABSTRAK
Sofyan A, Sakti AA, Karimy MF, Julendra H, Istiqomah L, Herdian H, Damayanti E, Suryani AE. 2014. Efektivitas probiotik, mikromineral terkorporasi khamir yang dikombinasikan dengan daun Azadirachta indica mengandung tanin terhadap fermentabilitas dan kecernaan Pennisetum hybrid. JITV 20(2): 95-104. DOI: http://dx.doi.org/10.14334/jitv.v20i2.1164

Eksplorasi imbuhan pakan organik untuk ternak saat ini terus dilakukan untuk menggantikan antibiotik sebagai pemacu pertumbuhan. Probiotik dari bakteri asam laktat telah digunakan secara luas untuk mendukung keseimbangan mikroba saluran pencernaan. Selain itu, mineral organik ditambahkan pada pakan untuk meningkatkan ketersediaan dalam mencegah kelainan metabolisme akibat defisiensi mineral. Penelitian ini bertujuan untuk mengevaluasi penambahan probiotik (Pediococcus acidilactici RS2) dan mikromineral terkorporasi khamir/micromineral enriched yeast (MEY) yang dikombinasikan dengan tanin dari daun mimba (Azadirachta indica) terhadap fermentabilitas rumput Raja ( $P$. hybrid) dengan menggunakan teknik produksi gas in vitro. Perlakuan terdiri dari P0 (kontrol/hijauan tanpa imbuhan), P1 (P0+MEY); P2 (P0+MEY+tanin); P3 (P0+Probiotik); P4 (P0+Probiotik+MEY), dan P5 (P0+Probiotik+MEY+tanin) yang disusun dalam rancangan acak lengkap dengan 3 ulangan setiap perlakuan. Suplementasi MEY $(\mathrm{P} 1)$, probiotik+MEY $(\mathrm{P} 4)$ dan probiotik+MEY+tanin $(\mathrm{P} 5)$ nyata $(\mathrm{P}<0,05)$ meningkatkan produksi gas hijauan tanpa berpengaruh pada asam lemak volatil (VFA), jumlah protozoa, produksi metana dan kecernaan in vitro. Produksi gas tertinggi tercatat pada hijauan yang diberi perlakuan P4 diikuti P5, P1, P2, P3 dan kontrol. Pengaruh perlakuan terhadap kinetika produksi gas menunjukkan perbedaan yang nyata pada inkubasi setelah 8 jam. Walaupun perlakuan hanya berpengaruh terhadap kinetika produksi gas (b, c dan total gas), berdasarkan analisis kluster-hirarki menunjukkan beberapa parameter yang terdiri dari asetat, propionat, kecernaan in vitro, jumlah protozoa dan produksi gas metana sangat berkorelasi dengan parameter kinetika produksi gas. Dapat disimpulkan bahwa fermentabilitas hijauan dapat ditingkatkan dengan suplementasi mineral organik maupun kombinasinya dengan probiotik maupun probiotik+tanin tanpa berpengaruh negatif terhadap kecernaan in vitro.
\end{abstract}

Kata Kunci: Fermentabilitas, Kecernaan In Vitro, Mineral Organik, Probiotik, Tanin

\section{ABSTRACT}

Sofyan A, Sakti AA, Karimy MF, Julendra H, Istiqomah L, Herdian H, Damayanti E, Suryani AE. 2015. Effectivity of probiotic, micromineral enriched yeast and their combination with Azadirachta indica leaves containing tannin on fermentability and digestibility of Pennisetum hybrid. JITV 20(2): 95-104. DOI: http://dx.doi.org/10.14334/jitv.v20i2.1164

Organic additive for animal had been explored to replace antibiotic growth promoter. Probiotic from lactic acid bacteria was widely used to support the microbial balances in digestive tract, while organic mineral was added into diets to improve bioavailability for preventing mineral deficiency disorders. This experiment was aimed to assess probiotic (Pediococcus acidilactici RS2) and micromineral enriched yeast (MEY) combined with tannin from neem (Azadirachta indica) leaves containing tannin on king grass $(P$. hybrid) fermentability using in vitro gas production technique. Treatments consisted of P0 (control/forage without additive), $\mathrm{P} 1$ (P0+MEY); P2 (P0+MEY+crude tannin); P3 (P0+Probiotic); P4 (P0+Probiotic+MEY), and P5 (P0+Probiotic+MEY+crude tannin). The study was arranged in a completely randomized design (CRD) with three replications in each treatment. Probiotic, MEY or tannin supplementation significantly increased $(\mathrm{P}<0.05)$ gas production without affecting volatile fatty acid, protozoa numbers, methane production and in vitro digestibility of forage. The highest cumulative gas production was found in forage treated by P4 followed by P5, P1, P5, P2, P3 and control. Kinetic of gas production was significantly affected by treatments after $8 \mathrm{~h}$ incubation. Although the treatments were only significantly affected gas production kinetic ( $b, c$ and total gas), the hierarchical cluster analysis indicated that some parameters consisted of acetate, propionate, in vitro digestibility, protozoa numbers, and methane production were closely correlated to the gas production kinetic parameters. It was concluded that either organic mineral supplementation or its combination with probiotic, and probiotic+tannin improved fermentabilty of forage without negative effect on in vitro digestibility.

Key Words: Fermentability, In Vitro Digestibility, Organic Mineral, Probiotic, Tannin 


\section{INTRODUCTION}

Ruminant contribute to meat and milk supply for human consumption. Low quality feedstuffs is the biggest constrain in ruminant productivity. Supplementation of feed additive such as antibiotic growth promoters (AGP) had been reported could improve the nutrient utilization and animal performance. However, feed additive containing AGP had been banned since January 2006 in accordance with pathogenic resistant risk and antibiotic residues in animal products and by-products (EC 2012).

Feed additive based on organic material had been explored to replace antibiotic in order to support the ruminant performance. Probiotic from lactic acid bacteria are widely used to support the microbial balances in digestive tract. Probiotic is microorganism that supports animal health through maintaining and improving the intestinal microbial balance and its immune response. It is necessary to consider this probiotic, because rumen constitutes an effective animal-microbe interdependency system from that each partner derives benefit to the host animal (Arokiyaraj et al. 2014). The role interdependency system was played by complex microbial community in which the domains bacteria, archaea, and eukarya that responsible for degrading fiber particle from forage as major energy sources (Fraga et al. 2014).

Many species of lactic acid bacteria were used as probiotic cultures for ruminant such as Lactobacillus animalis, L. paracasei, Bacillus coagulans (Agazzi et al. 2014), Pseudobutyrivibrio ruminis (Fraga et al. 2014) and Pediococcus acidilactici (Cobos et al. 2011; Arokiyaraj et al. 2014). Moreover, Cobos et al. (2011) revealed that $P$. acidilactici isolated from rumen lamb could survive in low $\mathrm{pH}$ condition (4.71-4.98) without causing negative effect on dry matter digestibility. It implies that $P$. acidilactici can be used as probiotic.

On the other side, productivity of ruminant was influenced by mineral deficiencies. Although diets was formulated based on the nutrient requirement, in some cases, ruminant metabolic disorder caused by mineral deficiency. Haenlein \& Anke (2011) reviewed that mineral deficiency is not only affect productivity parameters but also causes serious disease in ruminant. Organic mineral was added into diets to improve bioavailability for preventing mineral deficiency disorders. Artificial organic mineral (Selenium) involved yeast fermentation had been reported by Gresakova et al. (2013) that Se-yeast had higher absorption in digestive tract and body cell than $\mathrm{Se}$ inorganic form. In addition, Rabiee et al. (2010) reviewed that complex trace mineral in organic form increased ruminant productivity and health.

The other strategy to optimize feed digestibility is through methane reduction by tannin. Neem tree
(Azadirachta indica A. Juss) is tropical plant, its leaves contain secondary compound such as flavanoid and tannin (Pandey et al. 2014; Bhatta et al. 2015). Many researchers reported that plant secondary metabolites such as tannin could be used to modify ruminal fermentation in which improving feed utilization through reducing methane emission and therefore tannin is considered as a natural compound possessing methane mitigating effect (Bodas et al. 2012; Jayanegara et al. 2012).

Nutrition management strategy for enhancing ruminant production by supplementation of organic feed additive consisting of probiotic and organic mineral was necessary done. The availability of mineral in digestive tract affects the rumen microbe activity. This research was conducted to evaluate addition of probiotic (Pediococcus acidilactici RS2) and micromineral enriched yeast (MEY) combined with leaves containing tannin $(A$. indica) on king grass $(P$. hybrid) fermentability using in vitro gas production technique.

\section{MATERIALS AND METHODS}

\section{Sample preparation}

King grass (Pennisetum hybrid) was harvested on 70 days after previous cutting (harvest) and used as forage sample, then chopped and dried in oven at $60^{\circ} \mathrm{C}$ up to reach $12-14 \%$ of moisture content. The sample was ground and sieved into two $\mathrm{mm}$ particle size. Similarly, this procedure was applied in preparing leaf of Neem (Azadirachta indica A. Juss) which was used as tannin source.

Probiotic lactic acid bacteria ( $P$. acidilactici $\mathrm{RS} 2$ ) was isolated from cattle rumen and prepared by spraydrying method. Isolate was facultative anaerobically cultivated in deMann Rogosa Sharpe (MRS) Broth media for $18 \mathrm{~h}$ at $37^{\circ} \mathrm{C}$. The culture was centrifuged at $4500 \mathrm{rpm}$ for 10 minutes, then the pellet/biomass was mixed with the sterilized skim solution $(20 \% \mathrm{w} / \mathrm{v})$ and gum arabic $(1 \% \mathrm{w} / \mathrm{v})$. The solution was homogenized using the digital homogenizer at $8000 \mathrm{rpm}$ for 5 minutes. The culture solution was dried into powder form using the spray dryer (Lab Plant SD-Basic). Spray dryer operating conditions as follows: inlet air temperature was $110^{\circ} \mathrm{C}$, outlet air temperature was 55$60^{\circ} \mathrm{C}$, and the speed of pump was ' 3 ' speed unit. The dried culture viability was evaluated by spread plate method and adjusted to $10^{9} \mathrm{cfu} / \mathrm{g}$ of bacterial cell density.

Micromineral enriched yeast (MEY) was produced by inoculating $S$. cerevisiae ATCC 9763 into media fortified by micro minerals consisted of $\mathrm{Fe}, \mathrm{Mn}, \mathrm{Cu}$, Co, Zn, and I. Cassava (Manihot sp.) flour as a substrate for fermentation, and the formulation per $\mathrm{kg}$ substrate 
consisted of $\mathrm{FeCl}_{2} .4 \mathrm{H}_{2} \mathrm{O}(0.177 \mathrm{~g}), \mathrm{MnCl}_{2} .4 \mathrm{H}_{2} \mathrm{O}(7.129$ g), $\mathrm{CuSO}_{4} .5 \mathrm{H}_{2} \mathrm{O}(9.810 \mathrm{~g}), \mathrm{ZnSO}_{4} .7 \mathrm{H}_{2} \mathrm{O}(12.646 \mathrm{~g})$, $\mathrm{CoCl}_{2} \cdot 6 \mathrm{H}_{2} \mathrm{O}(0.192 \mathrm{~g})$, and $\mathrm{KI}(0.217 \mathrm{~g})$. Fermentation was conducted for 7 days in facultative condition then dried in oven at $55^{\circ} \mathrm{C}$ (up to $24-48 \mathrm{~h}, \mathrm{DM} 10 \%$ ), followed by ground and sieved into one $\mathrm{mm}$ particle size.

\section{Fermentability and in vitro digestibility assessment}

The sample and rumen liquid were prepared prior to in vitro assessment. Two ruminally fistulated Ongole crossbreed cattle adapted by feeding forage $(P$. hybrid $)$ and concentrate (80:20 in dry matter basis) were used as rumen liquor donor. Rumen fluid was taken using aspirator, and immediately transported in pre-warmed vacuum flask $\left(39^{\circ} \mathrm{C}\right.$ water temperature) and filtered.

In vitro fermentability was evaluated using in vitro gas production technique according to Menke \& Steingass (1988). Gas production kinetics was calculated based on the exponential equation according to Ørskov \& McDonald (1979). The exponential equation is $P=a+b\left(1-e^{-c t}\right)$ with describing $P$ is total gas production, $a$ is the gas production from soluble fraction, $b$ is the gas production from insoluble fraction, $c$ is the rate of gas production, $t$ is the time of incubation and $e$ is Euler's constant $(2.7183 \ldots)$. The estimated value of $a, b$ and $c$ were calculated by a fitting curve method using Neway Software developed by Chen (1997). This study was conducted based on Completely Randomized Design (CRD) with six treatments and three replications. Nutrient composition from each treatment was showed in Table 1 . The treatments were described as follows:

$$
\begin{aligned}
\mathrm{P} 0= & \text { control/forage } 380 \mathrm{mg}(\text { dry matter }=92.5 \%) \\
\mathrm{P} 1= & \mathrm{P} 0+3 \% \text { micromineral enriched yeast }(\mathrm{MEY}) \\
\mathrm{P} 2= & \mathrm{P} 0+3 \% \mathrm{MEY}+2 \% \text { crude tannin } \\
\mathrm{P} 3= & \mathrm{P} 0+0.1 \% \text { probiotic }\left(10^{9} \mathrm{cfu} / \mathrm{g}\right) \\
\mathrm{P} 4= & \mathrm{P} 0+3 \% \mathrm{MEY}+0.1 \% \text { probiotic } \\
\mathrm{P} 5= & \mathrm{P} 0+3 \% \mathrm{MEY}+2 \% \text { crude tannin }+0.1 \% \\
& \text { probiotic }
\end{aligned}
$$

Fermentation was conducted in $100 \mathrm{~mL}$ syringe glass (Fortuna model, Poulten and Graft Gmbh Germany). Two syringes containing rumen-buffer without sample (blank) was used in the experiment. All of syringes consisted of samples and blank were randomly incubated for 48 hours in an incubator at $39^{\circ} \mathrm{C}$.

Table 1. Nutrient composition of diets consisting of king grass supplemented by either MEY, probiotic or crude tannin

\begin{tabular}{lcccccc}
\hline \multirow{2}{*}{ Nutrients } & \multicolumn{5}{c}{ Treatment diets } \\
\cline { 2 - 7 } & P0 & P1 & P2 & P3 & P4 & P5 \\
\hline DM & 92.5 & 92.6 & 92.5 & 92.5 & 92.6 & 92.5 \\
CP (\%DM) & 11.7 & 11.4 & 11.7 & 11.7 & 11.4 & 11.7 \\
CF (\%DM) & 25.5 & 25.2 & 24.8 & 25.5 & 25.2 & 24.8 \\
EE (\%DM) & 2.1 & 2.0 & 2.1 & 2.1 & 2.0 & 2.1 \\
NFE (\%DM) & 45.0 & 46.0 & 46.1 & 45.0 & 46.0 & 46.1 \\
CT (\%DM) & - & - & 0.28 & - & - & 0.28 \\
\hline
\end{tabular}

$\mathrm{P} 0=P$. hybrid;

$\mathrm{P} 1=\mathrm{P} 0+$ Micromineral Enriched Yeast $/ \mathrm{MEY}$

$\mathrm{P} 2=\mathrm{P} 0+\mathrm{MEY}+$ crude tannin;

$\mathrm{P} 3=\mathrm{P} 0+$ Probiotic;

$\mathrm{P} 4=\mathrm{P} 0+$ Probiotic $+\mathrm{MEY}$;

$\mathrm{P} 5=\mathrm{P} 0+$ Probiotic $+\mathrm{MEY}+$ crude tannin;

$\mathrm{DM}=$ dry matter;

$\mathrm{CP}=$ crude protein

$\mathrm{CF}=$ crude fiber;

$\mathrm{EE}=$ ether extract;

$\mathrm{NFE}=$ nitrogen free extract;

$\mathrm{CT}=$ condensed tannin

Nutrient composition was calculated by reference consisted of King grass (Rumiyati 2006); A. indica (Obun et al. 2013; Bhatta et al. 2015);

DM content was confirmed by re-analysing in our experiment 
Cumulative gas production was recorded at $0,1,2$, $4,6,8,12,18,24,36$ and 48 hours. After $48 \mathrm{~h}$ incubation gas was released and the fluid contained in syringe was taken for analysis of protozoa population, VFA, and in vitro dry matter and organic matter digestibility. Dry matter (DM) and organic matter (OM) of substrate from each syringe was measured according to AOAC (2012) method. Percentage of DM or OM differences between initial and after incubation and corrected with blank were calculated as in vitro digestibility as followed the formula:

$$
\operatorname{IVDMD}=\frac{[\mathrm{DM} f-(\mathrm{DM} r-\mathrm{DM} b)]}{\mathrm{DM} f} \times 100 \%
$$

and

$$
\text { IVOMD }=\frac{[\mathrm{OM} f-(\mathrm{OM} r-\mathrm{OM} b)]}{\mathrm{OM} f} \times 100 \%
$$

Where IVDMD: in vitro dry matter digestibility, IVOMD: in vitro organic matter digestibility, DMf: dry matter of feed, DM $r$ : dry matter of residue, $\mathrm{DM} b$ : dry matter of blank, OMf: organic matter of feed, $\mathrm{OM} r$ : organic matter of residue, and $\mathrm{OM} b$ : organic matter of blank.

\section{Analysis of volatile fatty acid, methane, and counting protozoa}

Volatile fatty acid (VFA) product from fermentation was measured according to Sun et al. (2013). Sample was prepared by addition of meta-phosphoric acid and stored at $-20^{\circ} \mathrm{C}$ before analysis. Analysis of VFA was performed by gas chromatography (Shimadzu type $8 \mathrm{~A}$ ) with packed column GP10\% $\mathrm{SP}-1200 / 1 \% \mathrm{H}_{3} \mathrm{PO} 4$ on 80/100 Chromosorb WAW (Supelco, Bellefonte, PA).

Analysis of methane $\left(\mathrm{CH}_{4}\right)$ from gas production was conducted after $18 \mathrm{~h}$ of incubation. Ten $\mathrm{ml}$ of gas from each sample was taken using vacuum syringe then injected into a vacuum tube. Gas samples were analyzed using gas chromatography (Shimadzu GC14B) completed with ProparakQ Column $\left(50^{\circ} \mathrm{C}\right)$ with helium (He) carrier gas at $60 \mathrm{ml} / \mathrm{min}$ flow rate and a flame ionization detector $\left(150^{\circ} \mathrm{C}\right)$ as described by Duan et al. (2013). The number of protozoa was counted using hemocytometer and stained with methyl green formalin saline/MFS. MFS solution contained $100 \mathrm{~mL}$ of $35 \%$ formaldehyde solution, $900 \mathrm{~mL}$ of distilled water, $0.6 \mathrm{~g}$ of methyl green and $8.0 \mathrm{~g}$ of $\mathrm{NaCl}$ as described by Sun et al. (2013).

\section{Data analysis}

Variables measured were in vitro digestibility (IVDMD and IVOMD), fermentability (gas production kinetics, $a, b$ and $c$ ), individual volatile fatty acids
(VFA), non-glucogenic ratio (NGR), protozoa numbers, methane production $\left(\mathrm{CH}_{4}\right)$ and $\mathrm{CH} 4 / \mathrm{OMD}$ ratio. The protozoa cell number was converted to logarithmic transformation. Data were evaluated by analysis of variance (ANOVA) and the differences among mean treatments were analyzed using post hoc test of Duncan's Multiple Range Test performed by the CoSTAT statistical software (Cohort 2008).

Analysis of interrelationship parameters was performed by hierarchical clustering analysis/HCA (Ametaj et al. 2010). Visualization of HCA was performed using dendogram-heatmap that constructed using 'heatmap.2 function from 'gplots library' in the R-statistical software (R Core Team 2013). Pretreatment data were calculated based on the relative differential data from treatments and control using fomula $x_{\mathrm{t}} / x_{0}-1$ where $x_{t}$ and $x_{o}$ denote treatment and control data respectively.

\section{RESULTS AND DISCUSSIONS}

Ruminal fermentability characteristics evaluated by in vitro gas production were showed on Table 2 . Total gas, gas production rate $(c)$ and gas production from insoluble fraction $(b)$ of forage was significantly affected by treatments $(\mathrm{P}<0.05)$. The other parameters consisted of gas production from soluble fraction $(a)$ or total fraction $(a+b)$ from forage had tendency $(\mathrm{P} \sim 0.11)$ affected by treatments. Forage was supplemented by probiotic+MEY (P4) generated the highest gas production compared to the others.

Gas production generated from the soluble fraction (a) resulted negative value that indicated ruminal microbes need adaptation time (lag phase) before degrading the insoluble particle. The previous study reported by Arhab et al. (2010) that negative value could be interpreted as lag time of ruminal microbes to degrade soluble fraction and then to adhere to cellulosic fraction.

Production of total volatile acid, acetate (C2), propionate $(\mathrm{C} 3)$, butyrate $(\mathrm{C} 4)$ and non glucogenic ratio (NGR) indicated no significant difference $(\mathrm{P}>0.05)$ among treatments (Table 2). Total VFA was varied between $43 \sim 62 \mathrm{mM}$ per $\mathrm{mL}$ of rumen fluid. Production of VFA from forage treated by P1, P3, P5, and $\mathrm{P} 4$ were $43.2 \%, 26.2 \%, 19.3 \%$ and $7.7 \%$ higher than P2 and control (P0). Non glucogenic ratio seemed constant in all treatments with average value 4.42 except for P5 treatment (13\% higher than control), however proportion of $\mathrm{C} 2: \mathrm{C} 3: \mathrm{C} 4$ was constant about 70:20:10 for all treatments. Based on the ruminal fermentation stoichiometry, individual VFA proportion consisting of C2, C3 and C4 were 60-70\%, 20-30\% and $10-15 \%$ respectively (Wolin et al. 1997). 


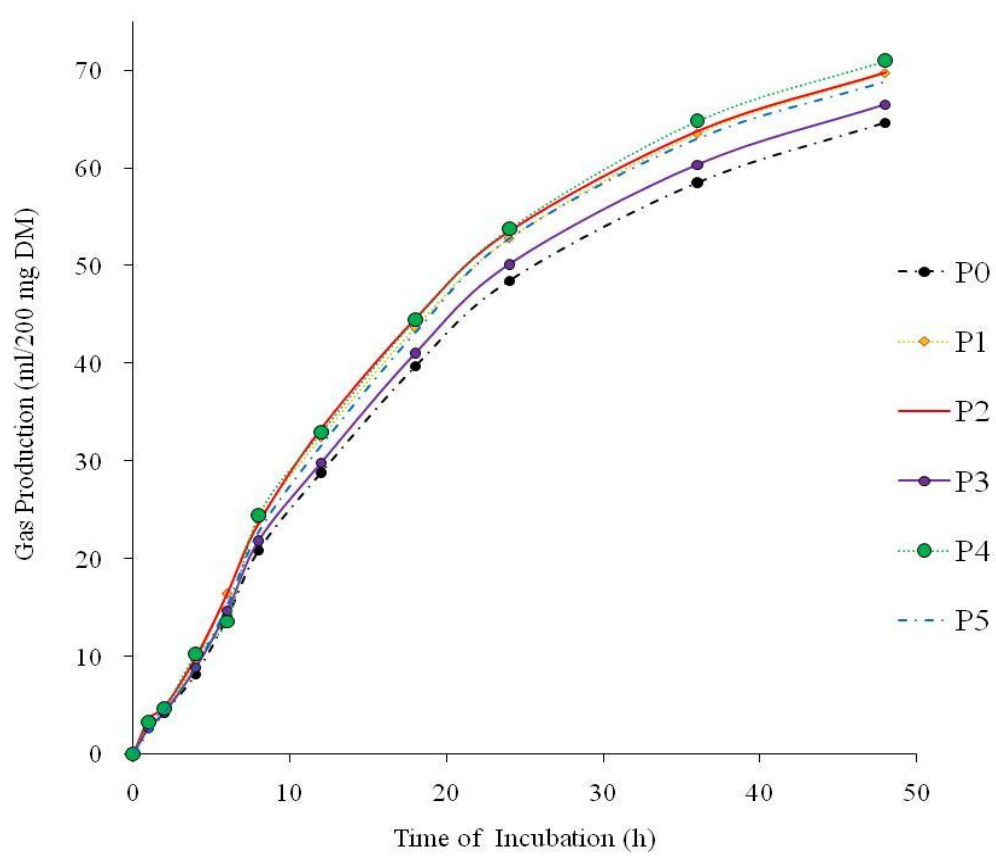

P0 (P. hybrid); P1 (P0+micromineral enriched yeast/MEY); P2 (P0+MEY+crude tannin); P3 (P0+Probiotic); P4 (P0+Probiotic+MEY); P5 (P0+Probiotic+MEY+crude tannin)

Figure 1. Cumulative gas production of forage supplemented by probiotic, micromineral enriched yeast (MEY) and crude tannin incubated during $48 \mathrm{~h}$

In the present study, in vitro dry matter (IVDMD), organic matter (IVOMD) digestibility and production of volatile fatty acid (VFA) were not influenced by treatments either probiotic or combination with MEY and tannin. The similar result was also reported by Sun et al. (2013), that probiotic Bacillus subtilis supplementation on total mix ration (TMR) did not affect the dry matter digestibility during $24 \mathrm{~h}$, moreover it decreased significantly $(\mathrm{P}<0.05)$ neutral detergent fiber (NDF) digestibility. In contrast, Fraga et al. (2014) studied that addition of probiotic consisted of Pseudobutyrivibrio ruminis significantly increased total VFA concentration of wheat straw. It seems that probiotic supplementation affected in vitro digestibility might be influenced by culture adaptation associated with complexity in ruminal ecosystem.

Compared to other animal, supplementation of feed additive complex containing chelated/organic mineral, probiotic, yucca extract indicated that no significant improvement of feed digestibility in horse (Gordon et al. 2013). This varying result could be caused by many factors such as age of animal, viability of probiotic culture, and initial mineral status of the animals.
Fermentability evaluated by in vitro gas production was indicated by kinetic gas production parameters. Based on the kinetic curve of gas production, all treatments did not significantly influence gas production up to 8 hours of incubation. However, after 8 hours incubation, gas production from forage was significantly affected by treatment (Figure 1). The highest cumulative gas production found at forage treated by $\mathrm{P} 4$ followed by P5, P1, P5, P2, P3, and control. It was closely related to the kinetics parameter ( $a, b$, and $c$ values) which indicated that gas production in probiotic treatment and control was lower than others (Table 2).

Methane emission from ruminant reflected the energy lost. The amount of methane production conversely indicated the nutrient utilization. Methane $\left(\mathrm{CH}_{4}\right)$ production and methane corrected by organic matter digestibility $\left(\mathrm{CH}_{4} / \mathrm{OMD}\right)$ during incubation showed similar result in all treatments, around $14.05 \pm 0.35 \%$ and $32.11 \pm 4.25 \%$ respectively. $\mathrm{CH}_{4}$ and $\mathrm{CH}_{4} / \mathrm{OMD}$ clearly tended to decrease on treatments $\mathrm{P} 2$ and P3. 
Table 2. Gas production kinetic, volatile fatty acid production and in vitro digestibility of forage supplemented by probiotic, micromineral enriched yeast (MEY) and crude tannin

\begin{tabular}{|c|c|c|c|c|c|c|}
\hline \multirow{2}{*}{ Variables } & \multicolumn{5}{|c|}{ Treatments } & \multirow{2}{*}{ P-value } \\
\hline & P0 & P1 & P2 & P3 & P4 & \\
\hline
\end{tabular}

Fermentability/Gas production kinetic parameters

\begin{tabular}{|c|c|c|c|c|c|c|c|}
\hline$a(\mathrm{~mL})$ & $-0.68 \pm 0.27$ & $-0.81 \pm 0.14$ & $-0.65 \pm 0.29$ & $-0.76 \pm 0.15$ & $-0.66 \pm 0.10$ & $-1.09 \pm 0.06$ & 0.097 \\
\hline$b(\mathrm{~mL})$ & $47.52 \pm 0.61^{\mathrm{ab}}$ & $48.12 \pm 1.27^{\mathrm{ab}}$ & $46.92 \pm 0.80^{\mathrm{b}}$ & $47.72 \pm 0.16^{\mathrm{ab}}$ & $48.87 \pm 0.48^{\mathrm{a}}$ & $48.86 \pm 0.67^{\mathrm{a}}$ & $0.046^{*}$ \\
\hline$c(\mathrm{~mL} / \mathrm{h})$ & $0.042 \pm 0.002^{\mathrm{b}}$ & $0.046 \pm 0.001^{\mathrm{a}}$ & $0.047 \pm 0.002^{\mathrm{a}}$ & $0.043 \pm 0.001^{\mathrm{b}}$ & $0.045 \pm 0.001^{\mathrm{ab}}$ & $0.044 \pm 0.001^{\mathrm{ab}}$ & $0.036^{*}$ \\
\hline$a+b(\mathrm{~mL})$ & $46.84 \pm 0.35$ & $47.32 \pm 1.38$ & $46.28 \pm 1.01$ & $46.95 \pm 0.08$ & $48.21 \pm 0.49$ & $47.76 \pm 0.67$ & 0.111 \\
\hline Gas (48h) (mL) & $40.25 \pm 0.57^{\mathrm{d}}$ & $41.71 \pm 0.69^{\mathrm{ab}}$ & $40.92 \pm 0.56^{\mathrm{bcd}}$ & $40.39 \pm 0.16^{\mathrm{cd}}$ & $42.22 \pm 0.42^{\mathrm{a}}$ & $41.24 \pm 0.27^{\mathrm{bc}}$ & $0.002^{*}$ \\
\hline \multicolumn{8}{|c|}{ Volatile fatty acids } \\
\hline Acetate $(\mathrm{mM})$ & $30.55 \pm 16.18$ & $43.82 \pm 7.36$ & $29.66 \pm 11.64$ & $39.28 \pm 1.37$ & $33.43 \pm 17.34$ & $36.80 \pm 10.78$ & 0.684 \\
\hline Propionate (mM) & $8.64 \pm 4.32$ & $12.10 \pm 1.69$ & $8.96 \pm 2.82$ & $10.80 \pm 0.23$ & $9.12 \pm 4.03$ & $9.40 \pm 2.93$ & 0.691 \\
\hline Butyrate (mM) & $3.97 \pm 1.54$ & $5.88 \pm 1.27$ & $4.56 \pm 1.59$ & $4.39 \pm 1.58$ & $3.94 \pm 2.04$ & $5.30 \pm 2.73$ & 0.587 \\
\hline Total VFA (mM) & $43.16 \pm 22.03$ & $61.80 \pm 10.27$ & $43.19 \pm 15.80$ & $54.48 \pm 1.39$ & $46.49 \pm 23.40$ & $51.50 \pm 16.37$ & 0.703 \\
\hline NGR & $4.44 \pm 0.14$ & $4.58 \pm 0.18$ & $4.27 \pm 0.28$ & $4.45 \pm 0.15$ & $4.38 \pm 0.52$ & $5.01 \pm 0.16$ & 0.308 \\
\hline \multicolumn{8}{|c|}{ In vitro digestibility } \\
\hline IVDMD (\%) & $39.40 \pm 1.68$ & $42.64 \pm 2.82$ & $43.10 \pm 3.27$ & $42.58 \pm 4.84$ & $41.95 \pm 1.02$ & $42.70 \pm 1.31$ & 0.638 \\
\hline IVOMD (\%) & $41.11 \pm 1.61$ & $43.46 \pm 2.95$ & $45.11 \pm 4.33$ & $49.50 \pm 12.33$ & $42.80 \pm 0.86$ & $50.39 \pm 12.09$ & 0.586 \\
\hline
\end{tabular}

P0 (P. hybrid); P1 (P0+micromineral enriched yeast/MEY); P2 (P0+MEY+crude tannin); P3 (P0+Probiotic); P4 (P0+Probiotic+MEY); P5 (P0+Probiotic+MEY+crude tannin). Gas production from soluble fraction (a); and insoluble fraction (b); rate of gas production (c); IVDMD: In vitro Dry Matter Digestibility; IVDMD: In vitro Organic Matter Digestibility; * Significant Difference 


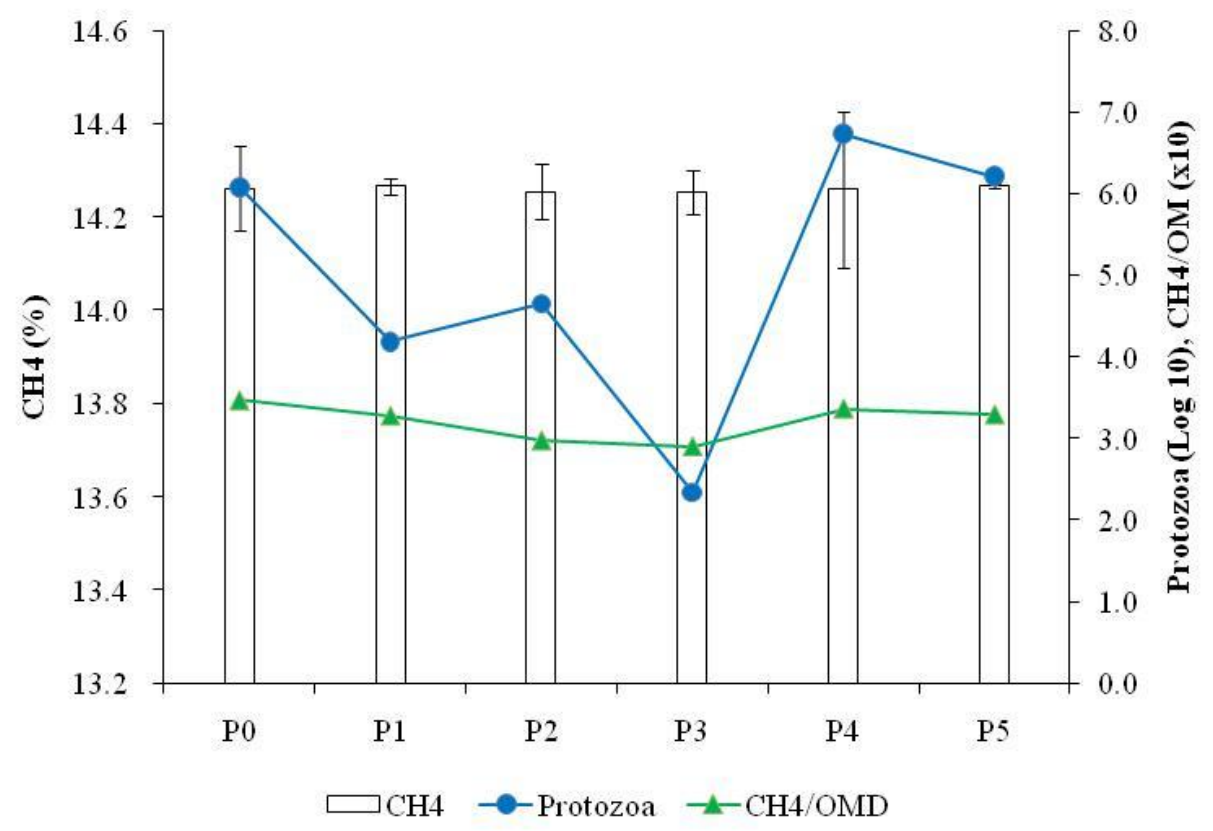

P0 (P. hybrid); P1 (P0+micromineral enriched yeast/MEY); P2 (P0+MEY+crude tannin); P3 (P0+Probiotic); $\mathrm{P} 4$ (P0+Probiotic+MEY); P5 (P0+Probiotic+ MEY+crude tannin)

Figure 2. Protozoal cell number, methane production, and methane per organic mater digestibility $\left(\mathrm{CH}_{4} / \mathrm{OMD}\right)$ of forage supplemented by probiotic, micromineral enriched yeast (MEY) and crude tannin

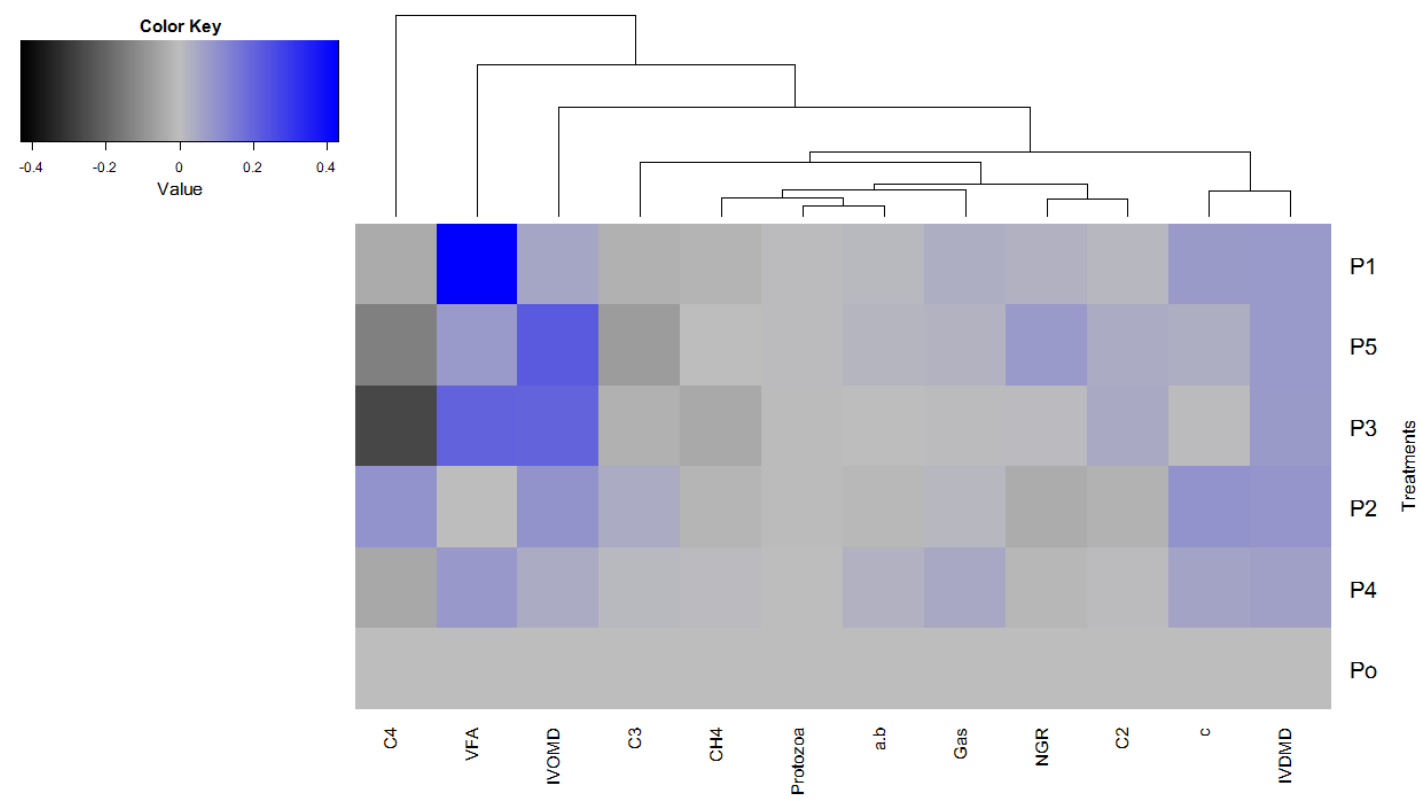

VFA: volatile fatty acids; C2: acetate; C3: propionate; C4: butyrate; CH4:methane; NGR: non-glucogenic ratio; IVDMD: in vitro dry matter digestibility; IVDMD: in vitro organic matter digestibility; P0 (P. hybrid); $\mathrm{P} 1$ (P0+micromineral enriched yeast/MEY); P2 (P0+MEY+crude tannin); P3 (P0+Probiotic); P4 (P0+Probiotic+MEY); P5 (P0+Probiotic+MEY+crude tannin). Color key: (0) denotes no change; (+) denotes value of proportion increase; (-) denotes value of proportion decrease

Figure 3. Dendogram-heatmap visualized hierarchical-clustering analysis of altering ruminal VFA, protozoa, methane production, fermentability, and in vitro digestibility 
Moreover, protozoa number appeared similar in all treatments was around $6.05 \log 10$ per $\mathrm{mL}$ rumen fluid (Figure 2). Supplementation of probiotic Propionibacterium could not alter methane production (Alazzeh et al. 2014). Indeed, Vyas et al. (2014) recommended to combine probiotic supplementation with concentrate to increase molar proportion of propionate and subsequently reduced the $\mathrm{CH}_{4}$ emissions.

Probiotic from lactic acid bacteria could reduce methane production by the mechanism of formate utilization in rumen, in turn formate would be used by methanogenic bacteria as methane precursor (Jeyanathan et al. 2014). In this study, inability probiotic to reduce methane might be correlated with constraint adaptability of culture in ruminal ecosystem. Similarly, Alazzeh et al. (2014) revealed that probiotic have no effect on methane reduction could be associated with adaptability with other ruminal microbes and including utilization of methane precursor. Moreover, probiotic also did not influence number of protozoa. Both of probiotic and protozoa indicated no antagonistic relationship as similar previously reported by Qadis et al. (2014).

Supplementation of tannin from A. indica leaves did not affect the methane production and protozoa number. It might be caused by low dosage of tannin $(0.28 \%)$ used in the present study. Currently, Bhatta et al. (2015) reported that addition of $2.5 \%$ A. indica leaves (contained $13.8 \%$ of condensed tannin) did not reduced methane production and protozoa number, however the methane production was inhibited when the addition was increase to $25 \%$.

Interrelationship parameters evaluated by hierarchical cluster analysis (HCA) indicated that proportion change of IVOMD, VFA and $\mathrm{C} 4$ were higher independently changed by treatment than other parameters (cluster I). Other parameters were categorized into cluster II $(\mathrm{C} 3, \mathrm{CH} 4$, protozoa, $a+b$, gas), cluster III (IVDMD and $c$ ), cluster IV (C2 and NGR). Cumulative gas production and IVDMD had higher similarities related to the change of treatment (Figure 3.). The tree clusters and their shorter Euclidean distance indicated higher similarities. Similarity between two metabolites or parameter was represented by branch height (Ametaj et al. 2010).

Organic matter digestibility of forage treated by P5 (probiotic+MEY+tannin) and P3 (probiotic), then total VFA from P1 reflected the higher increased differences than others while forage treated P4 (MEY+tannin) was not affect VFA and gas production. This result revealed that forage treated by probiotic either combining with organic mineral or tannin affected ruminal fermentation. Improving ruminal fermentation by feed additive containing lactic acid bacteria was previously reported Hillal et al. (2011). Otherwise, presence of tannin in P2 (MEY+tannin) resulted in VFA and fermentability lower than P1 might attribute to characteristic of condensed tannin in A. indica could inhibit ruminal microbes. Previously, Seresinhe et al. (2012) reported supplementation of condensed tannin could reduce forage fermentability by indicating gas production.

Methane production was closely related to the protozoa number. In the rumen, methane was generated by Archaea bacteria that consumed hydrogen. Archea activity was closely symbiosis with protozoa (Bhatta et al. 2015) and endosymbiotic between protozoa and Archaea responsible to methane formation (Belanche et al. 2015). Change of NGR was closely related to $C 2, C 3$ and $\mathrm{C} 4$ in which $\mathrm{C} 2$ was dominantly affected due to $60 \%$ of VFA. Moreover, gas production and degradation rate of particle affected the IVDMD. Sandoval-Castro et al. (2002) studied the relationship between digestibility and production gas parameter. Significant correlation between gas production and digestibility were influenced by many factors consisted of nutrient composition in which associated microbial ability to adhere and degrade the fraction of feed materials.

Overall, in vitro digestibility indicated nutrient utilization in the rumen which was attributed by gas production kinetic parameters and others parameters consisting of VFA, protozoa and methane production. In this study, presence of probiotic complemented by mineral organic or crude tannin had a positive effect on ruminal fermentation of forage.

\section{CONCLUSION}

Supplementation of feed additive contained micromineral enriched yeast (MEY) in combination with probiotic $P$. acidilactici RS2 or probiotic $+A$. indica leaves improved fermentability of king grass without affected volatile fatty acid, protozoa numbers, methane production, and in vitro digestibility.

\section{ACKNOWLEDGEMENT}

The authors would like to gratefully appreciate to the Indonesian Ministry of Research, Technology and Higher Education (Kemenristekdikti) and the Indonesian Institute of Sciences (LIPI) for supporting the research. We thank to the technician staff of Animal Feed and Nutrition Laboratory, the Research Unit for Processes Development and Chemical Engineering (UPT. BPPTK LIPI) for assistance during the experiment. 


\section{REFERENCES}

Agazzi A, Tirloni E, Stella S, Maroccolo S, Ripamonti B, Bersani C, Caputo JM, Dell'Orto V, Rota N, Savoini G. 2014. Effects of species-specific probiotic addition to milk replacer on calf health and performance during the first month of life. Ann Anim Sci.14:101-115.

Alazzeh AY, Smith AH, Beauchemin KA, Meale SJ, McAllister TA. 2014. Supplementing Propioni bacterium acidipropionici $\mathrm{P} 169$ does not affect methane production or volatile fatty acid profiles of different diets in in vitro rumen cultures from heifers. Acta Agric Scandinavica, Section A, Anim Sci. 1-9.

Ametaj BN, Zebeli Q, Saleem F, Psychogios N, Lewis MJ, Dunn SM, Xia J, Wishart DS. 2010. Metabolomics reveals unhealthy alterations in rumen metabolism with increased proportion of cereal grain in the diet of dairy cows. Metabolomics. 6:583-594.

Arhab R, Laadjimi K, Driss D, Djabri B, Bousseboua H. 2010. Evaluation of feed mixture interactions by using in vitro gas production method. Livest Res Rural Develop. Vol. 22 Issue 11. http://www.lrrd.org/lrrd22 /11/arha22217.htm.

Arokiyaraj S, Islam VIH, Bharanidharan R, Raveendar S, Lee J, Kim DH, Oh YK, Kim EK, Kim KH. 2014. Antibacterial, anti-inflammatory and probiotic potential of Enterococcus hirae isolated from the rumen of Bos primigenius. World J Microbiol Biotechnol. 30:21112118 .

[AOAC] Association of Official Analytical Chemist. 2012. Official Methods of Analysis, AOAC International. 19th ed. Washington DC (USA): Association of Official Analytical Chemist,

Belanche A, de la Fuente G, Newbold CJ. 2015. Effect of progressive inoculation of fauna-free sheep with holotrich protozoa and total-fauna on rumen fermentation, microbial diversity and methane emissions. FEMS Microbiol Ecol. 91, fiu026.

Bhatta R, M. Saravanan M, Baruah L, Prasad CS. 2015. Effect of graded level of tannin-containing tropical tree leaves on in vitro rumen fermentation, total protozoa and methane production. J Appl Microbiol. 118: 557-564.

Bodas R, Prieto N, García-González R, Andrés S, Giráldez FJ, López S. 2012. Manipulation of rumen fermentation and methane production with plant secondary metabolites. Anim Feed Sci Technol. 176:78-93.

Chen XB. 1997. Neway-excel microsoft office: a utility for processing data of feed degradability and in vitro gas production. Aberdeen (UK): Rowett Research Institute.

Cobos MA, deCoss AL, Ramirez ND, Gonzalez SS, FerreraCerrato R. 2011. Pediococcus acidilactici isolated from the rumen of lambs with rumen acidosis, 16s rRNA identification and sensibility to monensin and lasalocid. Res Vet Sci. 90:26-30.
Cohort. 2008. CoSTAT Version 6.400. Copyright 1998-2008. Cohort Software. 798. Lighthouse Ave, Montere, CA. 93940. USA.

Duan YF, Elsgaard L, Petersen SO. 2013. Inhibition of methane oxidation in a slurry surface crust by inorganic nitrogen: an incubation study. J Environ Qual. 42:507515.

[EC] European Commission. 2012. Plants and their extracts and other natural alternatives to antimicrobials in feeds. [Accessed on 01/08/2014]. http://ec.europa.eu/research/ health/infectious-diseases/antimicrobial-drug-resistance/ projects/068_en.html.

Fraga M, Perelmuter K, Valencia MJ, Martínez M, AbinCarriquiry A, Cajarville C, Zunino P. 2014. Evaluation of native potential probiotic bacteria using an in vitro ruminal fermentation system. Ann Microbiol. 64:11491156.

Gordon ME, Edwards MS, Sweeney CR, Jerina ML. 2013. Effects of added chelated trace minerals, organic selenium, yeast culture, direct-fed microbials, and Yucca schidigera extract in horses, Part I. Blood nutrient concentration and digestibility. J Anim Sci. 91:3899-3908.

Gresakova L, Cobanova K, Faix S. 2013. Selenium retention in lambs fed diets supplemented with selenium from inorganic or organic sources. Small Rumin Res. 111:7682.

Haenlein GFW, Anke M. 2011. Mineral and trace element research in goats: A review. Small Rumin Res. 95:2-19.

Hillal H, El-Sayaad, G, Abdella M. 2011. Effect of growth promoters (probiotics) supplementation on performance, rumen activity and some blood constituents in growing lambs. Arch Tierzucht. 54:607-617.

Jeyanathan J, Martin C, Morgavi DP. 2014. The use of directfed microbials for mitigation of ruminant methane emissions: a review. Animal. 8:250-261.

Jayanegara A, Leiber F, Kreuzer M. 2012. Meta-analysis of the relationship between dietary tannin level and methane formation in ruminants from in vivo and in vitro experiments. J Anim Physiol Anim Nutr. 96:365375.

Menke KH, Steingass H. 1988. Estimation of the energetic feed value obtained from chemical analysis and in vitro gas production using rumen fluid. Anim Res Dev. 28:755 .

Obun CO, Olatunji EA, CI. Ukim. 2013. Utilization of suncured neem leaf meal (Azadirachta indica A. Juss) based diets by finisher broiler chickens. [Retrieved on 03/04/2013]. http://en.engormix.com

Ørskov ER, McDonald I. 1979. The estimation of protein degradability in the rumen from incubation measurements weighted according to rate of passage. J Agric Sci. 92:499-503. 
Pandey G, Verma KK, Singh M. 2014. Evaluation of phytochemical antibacterial and free radical scavenging properties of Azadirachta indica (neem) leaves. Int J Pharm Pharmaceutic Sci. 6:444-447.

Qadis AQ, Goya S, Ikuta K, Yatsu M, Kimura A, Nakanishi S, Sato S. 2014. Effects of a bacteria-based probiotic on ruminal $\mathrm{pH}$, volatile fatty acids and bacterial flora of holstein calves. J Vet Med Sci. 76:877-885.

Rabiee AR, Lean IJ, Stevenson MA, Socha MT. 2010. Effects of feeding organic trace minerals on milk production and reproductive performance in lactating dairy cows: A meta-analysis. J Dairy Sci. 93:4239-4251.

R Core Team. 2013. R: A language and environment for statistical computing. R Foundation for Statistical Computing, Vienna, Austria. http://www.R-project.org/.

Rumiyati. 2008. Pengaruh imbangan jerami kacang tanah denganrumput raja dalam ransum terhadap performansapi Peranakan Friesian Holstein (PFH) jantan (Skripsi). [Surakarta (Indones)]: Universitas Sebelas Maret.

Sandoval-Castro CA, Capetillo-Leal C, Cetina-Gongora R, Ramirez-Aviles L. 2002. A mixture simplex design to study associative effects with an in vitro gas production technique. Anim Feed Sci Technol. 101:191-200.

Seresinhe T, Madushika SAC, Seresinhe Y, Lal PK, Ørskov ER. 2012. Effects of tropical high tannin non legume and low tannin legume browse mixtures on fermentation parameters and methanogenesis using gas production technique. Asian-Aust J Anim Sci. 25:1404-1410.

Sun P, Wang JQ, Deng LF. 2013. Effects of Bacillus subtilis natto on milk production, rumen fermentation and ruminal microbiome of dairy cows. Animal. 7:216-222.

Vyas D, McGeough EJ, Mohammed R, McGinn SM, McAllister TA, Beauchemin KA. 2014. Effects of Propionibacterium strains on ruminal fermentation, nutrient digestibility and methane emissions in beef cattle fed a corn grain finishing diet. Animal. 8:18071815 .

Wolin MJ, Miller TL, Stewart CS. 1997. Microbe-microbe interaction. In: Hobson PN, Stewart CS, editors. The Rumen Microbial Ecosystem. 2nd ed. London (UK): Chapman \& Hall. p. 467-491. 